\title{
THERMAL COMFORT CONDITION IN AFFANDI MUSEUM YOGYAKARTA
}

\author{
Azka Nidaa Millatina ${ }^{1 *}$, Nedyomukti Imam Syafii ${ }^{2}$ \\ ${ }^{1}$ Department of Architecture and Planning, Faculty of Engineering, Universitas Gadjah Mada, Yogyakarta, Indonesia \\ ${ }^{2}$ Department of Architecture and Planning, Faculty of Engineering, Universitas Gadjah Mada, Yogyakarta, Indonesia
}

\begin{abstract}
ARTICLE INFO

Thermal comfort is a basic human demand in interacting with space/architectural design. Determination of thermal comfort criteria can help the designer/architect in improving quality, function, and user thermal experience in an artificial environment. ISO 7730: 1994 standard states that the thermal sensation experienced by humans is the result of climate parameters (such as air temperature, radiation temperature, humidity, and wind speed) and human parameters (such as activity and clothing). These parameters were the focus of this study. The work program of this research collaboration was basically divided into 2 phases of activity, namely measuring and monitoring the conditions of thermal comfort in the Gallery 1 environment, Affandi Museum and providing recommendations for improvement of Gallery 1 thermal environment conditions. Primary data was taken from the indoor and outdoor measurement of air temperature, relative humidity and air velocity for 6 months. Physical architectural measurement of this study building and questionnaire methods followed the ASHRAE scale which was simplified to determine the level of thermal comfort, the scale of which was 2 (hot) to -2 (cold). The result of the measurement and analysis using a calculator based upon the ASHARE standard indicated that Gallery 1 of the Affandi Museum was in uncomfortable conditions. While the results of the questionnaire of 20 analyzes showed that at least $87,5 \%$ of respondents felt discomfort in Gallery 1, however, $60 \%$ of the respondent were still able to enjoy the collection and the atmosphere in gallery 1 . The effective temperature index which provides $27,5-27,6^{\circ} \mathrm{C}$ and $66,7 \% \mathrm{RH}$ as acceptable indoor environment in warm humid climate at Affandi Museum case.

\section{Keywords:}

Affandi Museum, Indoor Thermal Comfort, ASHRAE, Art Gallery
\end{abstract}

\section{Introduction}

Thermal comfort is a comfortable situation or condition. Comfortable situations are often called comfortable areas, and some are referred to as quality ventilation. Comfortable conditions are an expression, enjoyment of staying, healthy conditions, and cool sensations. Cold sensation affects or is influenced by psycho-physical. Thermal comfort is influenced by natural factors and human factors. Natural factors include solar radiation, energy, environment, economy, building configuration, and air. Whereas the human factor is one's activity/behavior and adaptability. Thermal comfort affects the level of stress and the effectiveness of one's work. Thermal comfort is very personal. This is because it is influenced or influential on a person's psychology.

Thermal comfort in buildings can be created by paying attention to fresh air, comfortable areas, occupant behavior, attainment of comfort, and air quality outside the building. The Affandi Museum is an art museum designed by Affandi in 1962 to accommodate his collection of paintings. Affandi is a painter who never study in architecture school. This museum is public and is visited by many local and international tourists. Affandi Museum has its own attraction, in addition to the collection of paintings, also from the exterior and interior aspects. Gallery 1 is the first and main gallery. Gallery 1 collection such as oil paintings and awards received by Affandi. Some of Affandi's personal collection items are also stored here, such as a Colt Gallant car and a onthe/ bicycle.

At first, Affandi Museum has many openings but later in 2018 they decided to close it. As result, Gallery 1 has thermal comfort problem. This study aims to determine the thermal comfort conditions in Gallery 1 Affandi Museum. 


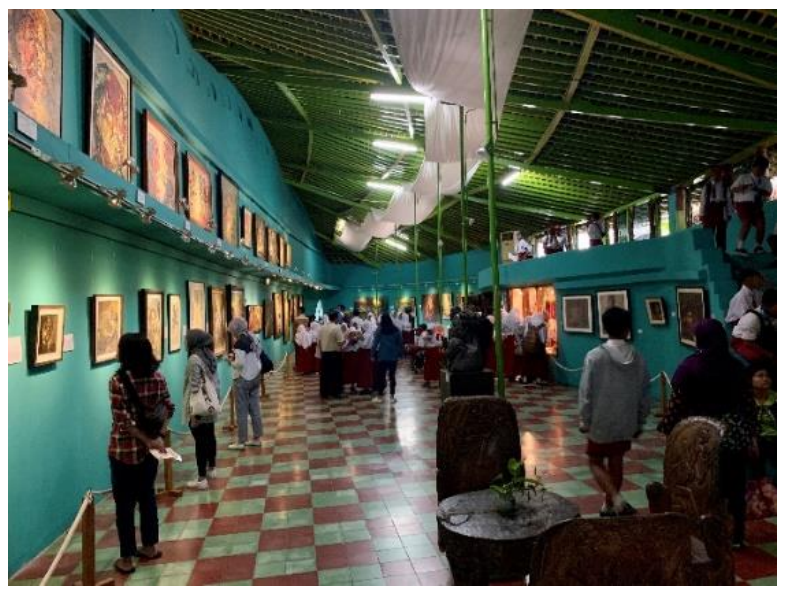

Figure 1. Thermal Comfort Sensation Source: www.affandi.org

As shown in Figure 1, gallery 1 is the main gallery and most visited place in Affandi Museum complex.

\section{Literature Review}

Thermal comfort is a physiological cooling which has a menaing as a sensation of comfort that is felt due to wind blowing against the skin. So the wind can blow the moisture or sweat and evaporate in the air (Satwiko, 2009).

The sensation of thermal comfort felt by humans is devided by psycho-physical scale of 7 points. The number is calculated from minus 3 to plus 3 which describes from cold to hot as shown in Figure 2.

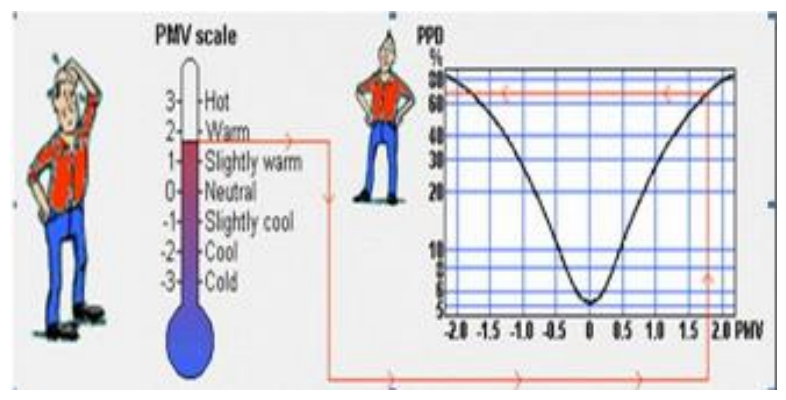

Figure 2. Thermal Comfort Sensation

Source: slideplayer.com/slide/4490690/

Thermal comfort variables are divided into physical comfort and non-physical comfort. Physical comfort factor is influenced by climate and non-physical comfort factors that influenced by human or user (Satwiko, 2009).

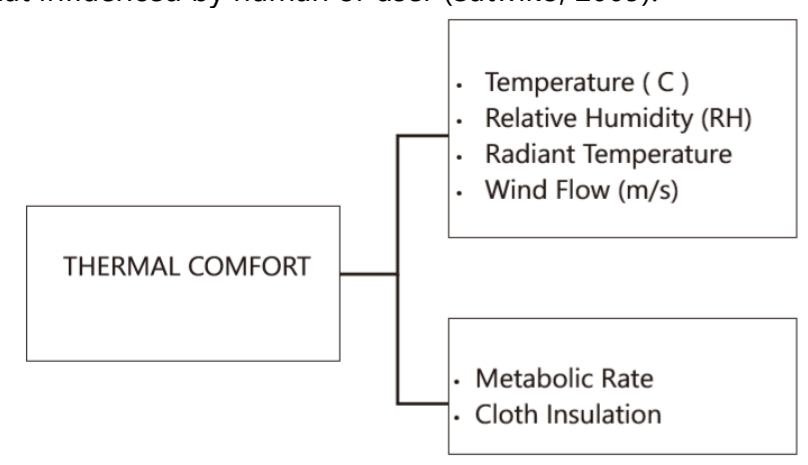

Figure 3. Thermal Comfort Variable Source: Satwiko (2009) and ASHRAE (2011)
Satwiko (2009) said, areas in the bioclimate chart that show thermally comfortable air condition or temperature are called the comfort zone. Thermal comfort of temperature varies and cannot be represented by a single number. That's because of the comfort is influenced by many factors. However, based on research, thermal comfort in tropical humid region can be concluded to be in the range of $24^{\circ} \mathrm{C}<\mathrm{T}<26^{\circ} \mathrm{C}, 40 \%<\mathrm{RH}<60 \%, 0,6 \mathrm{~m} / \mathrm{s}$ $<\mathrm{V}<1,5 \mathrm{~m} / \mathrm{s}$, with single layer clothing used and relaxing activities. The existing limits can be calculated based on existing factors, the average temperature of tropical humid region is usually high and has 27-32 degrees Celsius average temperature. Tropical people can feel comfortable in range 24 degrees Celsius, but sub-tropical person can feel quite hot and uncomfortable in 24 degrees Celsius.

\section{Thermal Comfort Standard Standar Nasional Indonesia 2011}

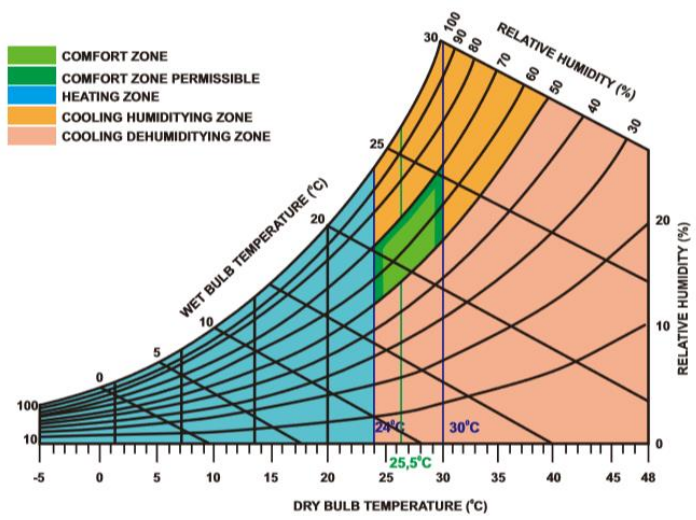

Figure 4. Thermal Comfort Standard SNI version Source: Standar Nasional Indonesia 6390(2011)

Based on energy conservation standard SNI, the planning conditions of buildings that are in lowland or coastal areas with an average maximum air temperature around $34^{\circ} \mathrm{C} \mathrm{DB}$ and $28^{\circ} \mathrm{C}$ WB (or average monthly temperature around $28^{\circ} \mathrm{C}$ ) is determined that:

a. Working space: dry bulb temperature around $24^{\circ} \mathrm{C}-27^{\circ} \mathrm{C}$ or $25,5^{\circ} \mathrm{C} \pm 1,5^{\circ} \mathrm{C}$, with relative humidity (RH) around $60 \% \pm 5 \%$.

b. Transit space (lobby, corridor): dry bulb temperature around $27^{\circ} \mathrm{C}-30^{\circ} \mathrm{C}$ or $28,5^{\circ} \mathrm{C} \pm 1,5^{\circ} \mathrm{C}$, with relative humidity $(\mathrm{RH})$ around $60 \% \pm 10 \%(\mathrm{BSN}, 2011)$.

\section{ASHRAE 2010}

According to ASHRAE Standard (2010), thermal comfort is a state of mind that expresses satisfaction with the surrounding thermal conditions. However, the conditions needed to obtain thermal comfort are not the same for everyone. There are six main factors that must be considered when determining thermal comfort, the six factors are as follows: 
Table 1. ASHRAE Variable

\begin{tabular}{|c|c|c|c|}
\hline No & Variable & Definition & Unit \\
\hline 1 & Metabolic rate (metabolic rate) & $\begin{array}{l}\text { rate of transformation of chemical energy into heat and mechanical } \\
\text { work by metabolic activity in an organism, usually expressed in units of } \\
\text { unit area of the total body surface }\end{array}$ & metric \\
\hline 2 & Clothing insulation & is resistance to heat transfer caused by clothing suits & clo \\
\hline 3 & Air temperature & temperature in the surrounding environment & Celcius \\
\hline 4 & Radiant temperature & $\begin{array}{l}\text { uniform surface temperature of an imaginary black enclosure, where the } \\
\text { user will exchange the same amount of radiant heat as in the actual } \\
\text { nonuniform space }\end{array}$ & Celcius \\
\hline 5 & Air speed & the rate of movement of air at a point, regardless of its direction & $\mathrm{m} / \mathrm{s}$ \\
\hline 6 & Humidity & $\begin{array}{l}\text { the ratio of the partial pressure of water vapor in the air with the } \\
\text { saturation pressure of water vapor at the same temperature and total } \\
\text { pressure. }\end{array}$ & $\%$ \\
\hline
\end{tabular}

Both of these standards, SNI and ASHRAE are thermal comfort standards that can be used in various studies. However, for this research, we will use the ASHRAE standard because the ASHRAE standard is more often used in various studies at research. In addition, a special software has been developed by Berkeley university that makes it easier to calculate thermal comfort (http://comfort.cbe.berkeley.edu/).

\section{Research Method}

\subsection{Research Location}

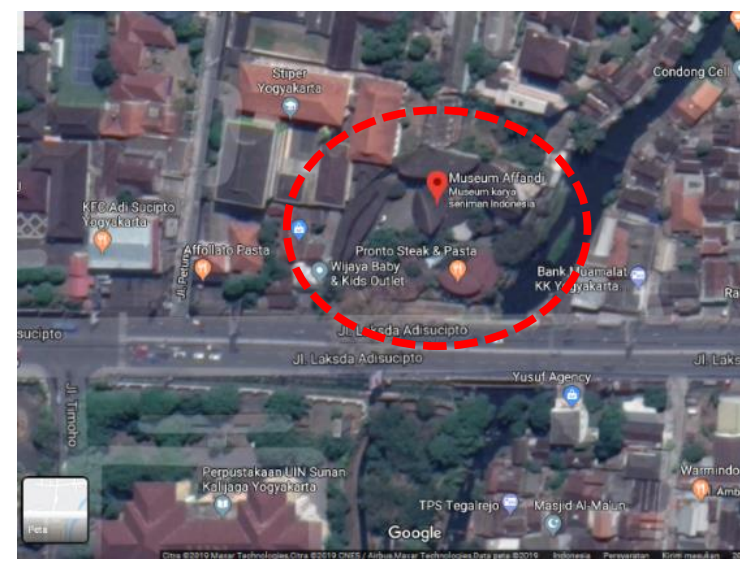

Figure 5. Affandi Museum

Source: Google Maps

Affandi Museum is located on Jalan Laksda Adisucipto No.167, Papringan, Caturtunggal, Depok, Sleman Regency, Special Region of Yogyakarta. Affandi Museum has an area of 3,500 square meters.

The main observational sites for research focus on gallery 1 or the main gallery at the Affandi Museum. The first gallery $\left(314,6 \mathrm{~m}^{2}\right)$ was built in 1962 and officially opened in 1974. The original compound comprised of the first gallery and the house of Affandi. It was built gradually and designed by Affandi himself. Affandi's house as well as the first gallery took shape of banana leaves. Affandi chose the shape of banana leaves because of specific reason. Once there was chicken pox out breaks which no way to cure it at that time, no vaccine or medicine. His brothers and sisters including Affandi were also exposed to chicken pox. So his parents used the banana leaves to cover their body in order to cool down it and not to be swarmed by flies. That story inspired him to adopt its shape for the roofing of his house and museum. Retrospective works of Affandi are on display in this gallery, consist of sketches on papers; watercolor; pastel; and oil paintings on canvas, and a number of selected art masterpiece by Affandi. Also his statues made form clay and cement, and a reproduction of statue depicting Affandi and his daughter Kartika and his favourite car a 1976 Mitsubishi Gallant.

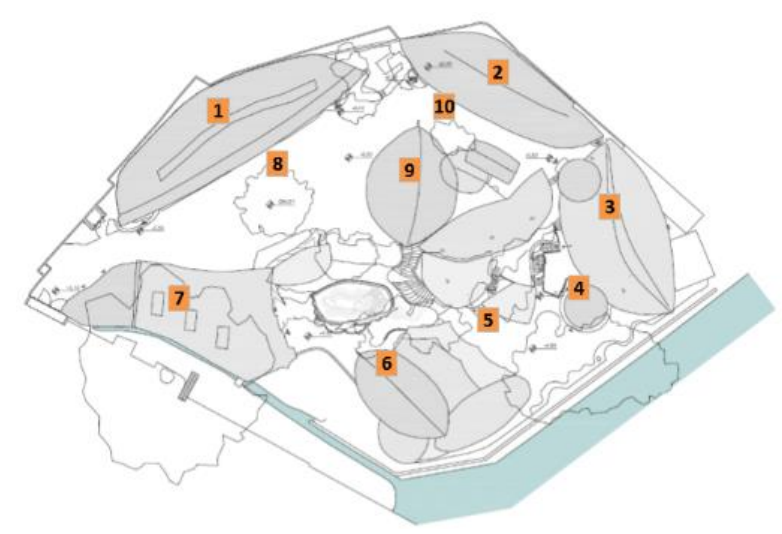

Figure 6. Affandi Museum Site Plan Source: TU Wien (2015)

Table 2 Affandi Museum Room and Observation

\begin{tabular}{|c|c|c|}
\hline No & $\begin{array}{l}\text { Room } \\
\text { Name }\end{array}$ & Notes \\
\hline 1 & Gallery 1 & $\begin{array}{l}\text { Main Gallery, Art gallery (Oil } \\
\text { Painting), Measurement and } \\
\text { observation focused on gallery } 1 . \\
\text { Questionnaire main focused in } \\
\text { gallery } 1 .\end{array}$ \\
\hline 2 & Gallery 2 & $\begin{array}{l}\text { Second gallery, art gallery (painting } \\
\text { with ink), observation and } \\
\text { questionnaire. Measurement only at } \\
26 \text { august } 2019 \text { for compare data. }\end{array}$ \\
\hline 3 & Gallery 3 & $\begin{array}{l}\text { Third gallery, art gallery (painting), } \\
\text { observation and questionnaire. }\end{array}$ \\
\hline
\end{tabular}




\begin{tabular}{|c|c|c|}
\hline & & $\begin{array}{l}\text { Measurement only at } 26 \text { august } \\
2019 \text { for compare data. }\end{array}$ \\
\hline 4 & $\begin{array}{l}\text { Tower- } \\
\text { gardu } \\
\text { pandang }\end{array}$ & $\begin{array}{l}\text { Tower, observation and } \\
\text { questionnaire. Measurement only at } \\
26 \text { august } 2019 \text { for compare data. }\end{array}$ \\
\hline 5 & Courtyard & $\begin{array}{l}\text { Courtyard, observation and } \\
\text { questionnaire. Measurement only at } \\
26 \text { august } 2019 \text { for compare data. }\end{array}$ \\
\hline 6 & Steakhouse & $\begin{array}{l}\text { Steakhouse, observation and } \\
\text { questionnaire. Measurement only at } \\
26 \text { august } 2019 \text { for compare data. }\end{array}$ \\
\hline 7 & Gallery 4 & $\begin{array}{l}\text { Gallery Gadjahwong located near } \\
\text { Gadjah Wong river, it is more like a } \\
\text { studio for kids or adult learn how to } \\
\text { makes a painting. The observation } \\
\text { and questionnaire taken here too. } \\
\text { Measurement only at } 26 \text { august } \\
2019 \text { for compare data. }\end{array}$ \\
\hline 8 & $\begin{array}{l}\text { Entrance } \\
\text { area }\end{array}$ & $\begin{array}{l}\text { Ticketing corner, bench and parking } \\
\text { zone for motorcycle and car, } \\
\text { observation and questionnaire. } \\
\text { Measurement only at } 26 \text { august } \\
2019 \text { for compare data. }\end{array}$ \\
\hline 9 & $\begin{array}{l}\text { Café } \\
\text { Loteng }\end{array}$ & $\begin{array}{l}\text { Cafe, The observation and } \\
\text { questionnaire. Measurement only at } \\
26 \text { august } 2019 \text { for compare data. }\end{array}$ \\
\hline 10 & $\begin{array}{l}\text { Front of } \\
\text { gallery }\end{array}$ & $\begin{array}{l}\text { Small courtyard, observation and } \\
\text { questionnaire. Measurement only at } \\
26 \text { august } 2019 \text { for compare data. }\end{array}$ \\
\hline
\end{tabular}

\subsection{Field Measurement study}

The study began with an observational survey conducted on August 26, 2019, to collect data on microclimatic conditions in the region as well as occupants' perceptions of data about these conditions. During this survey, the researchers took measurements of temperature, humidity and wind speed and conducted observations of behavior and simple interviews from visitors. Previously, measurement or retrieval of microclimate data (air temperature, humidity and wind speed) has been carried out continuously by Danube University Krems from Austria in collaboration with UGM since January 2019 until planned for completion in January 2020. Measurement data was taken per 5 minutes with measurement point as shown in figure 1 . In this study, the data had been collected and processed data from January until July 2019.

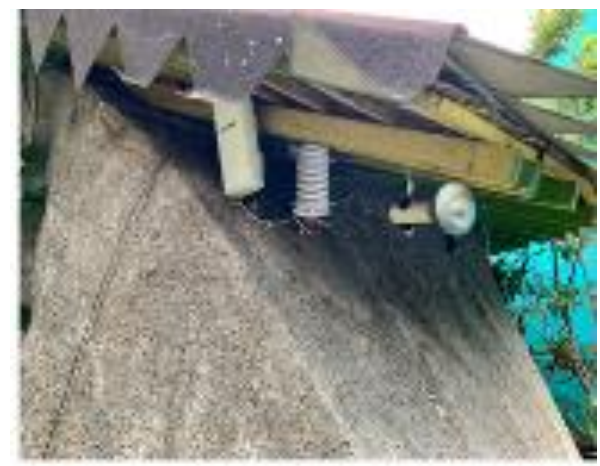

Figure 7. Multimeter Position Source: Author (2019)

The measuring instrument used in this study was a multimeter mounted on the interior and exterior walls in gallery 1 . This multimeter measured temperature, $\mathrm{RH}$, noise, and wind speed. The measurements were recorded

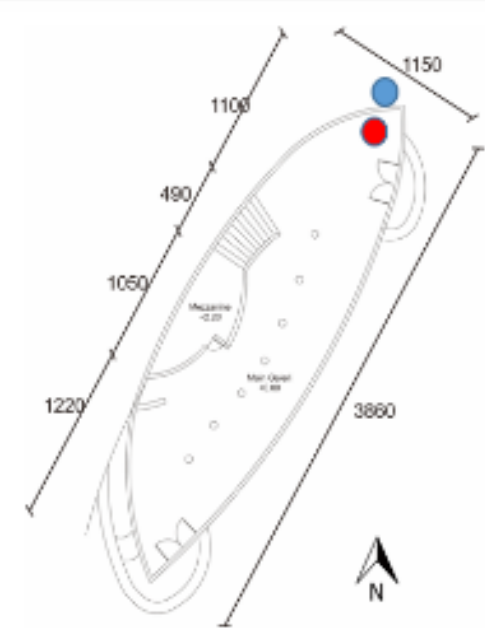

Figure 8. Multimeter Position, Blue is Outdoor and Red is Indoor Source: Author (2019)

every 5 minutes. While interior air velocity measurements were carried out at 4 points using an anemometer.

\section{Anemamebertoak \\ $\square$ Standing $A C$ pesition}

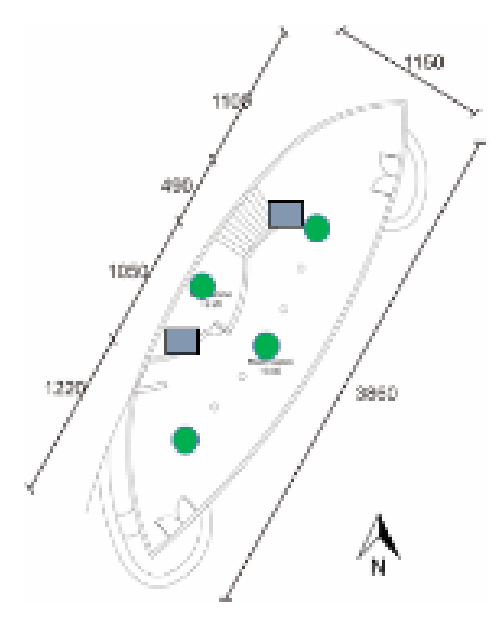

Figure 9. Anemometer Position

Source: Author (2019)

\subsection{Questionnaire Method}

The questionnaire method aimed to record the thermal comfort felt by the occupants and the contents of the questionnaire mainly involved indoor thermal sensation, as shown in Figure 10. The indoor thermal conditions were assessed by selecting the thermal sensations, humidity sensations, wind flow, and design sensations using the evaluation scale listed in Table 3.

The respondents were 20 UGM students, 7 males, and 13 females. All of the respondents did the same activity 
Thermal Comfort in Affandi Museum Universitas Gadjah Mada \& Affandi Museum \& Danube University Krems

August 26th, 2019
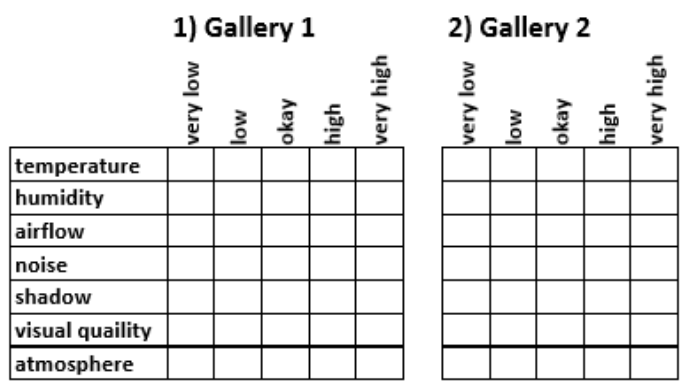

2) Gallery 3

4) Observation Tower 5) Courtyard
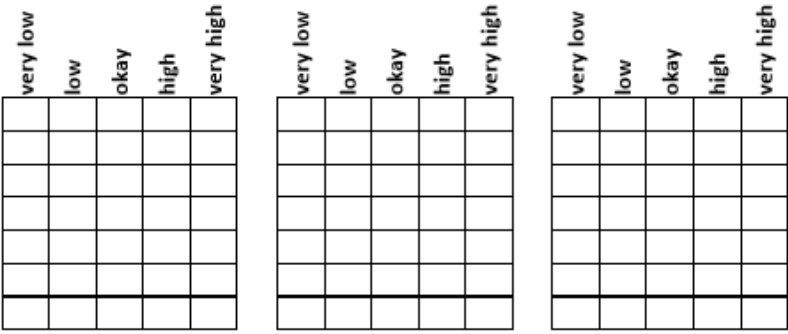

What would you like to do here? (number of answers)
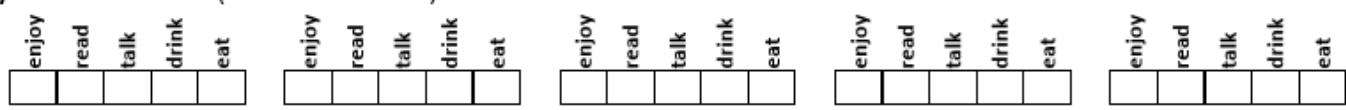

What makes this place special?
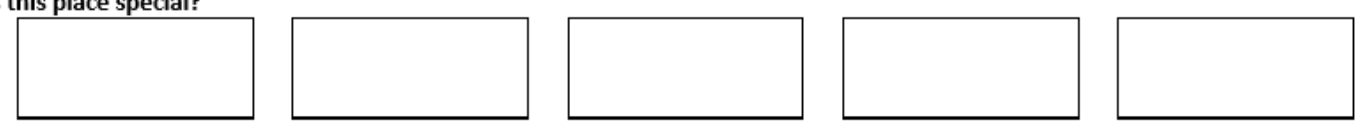

What would you like to improve, add to this place?
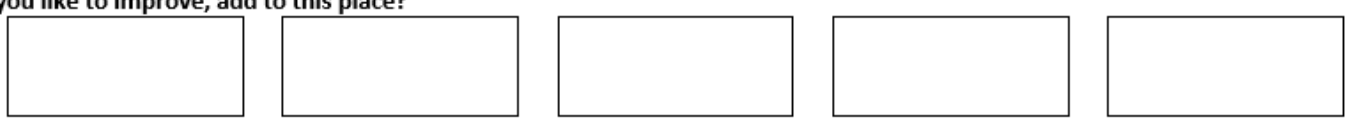

Research supported by the ASEAN-European Academic University Network (ASEA-UNINET)

Figure 10. Questionnaire Sheet

Source: Author (2019)

(standing, relaxing, and enjoying the museum) and wore standard summer clothing (shirt, jeans, trousers, and veil for some females). All respondents were between 23-30 years old.

Table 3. Index Scale of Self Evaluation

\begin{tabular}{lllll}
\hline Scale & Note & Temperature & Rh & $\begin{array}{l}\text { Wind } \\
\text { Speed }\end{array}$ \\
\hline 2 & Very low & Cold & dry & Stagnant \\
\hline 1 & Low & Slightly cool & $\begin{array}{l}\text { Slightly } \\
\text { dry }\end{array}$ & $\begin{array}{l}\text { Gently } \\
\text { breeze }\end{array}$ \\
\hline 0 & Okay & Neutral & Neutral & Neutral \\
\hline-1 & High & Slightly warm & Slightly & Slightly \\
humid & draught \\
\hline-2 & Very & Hot & Humid & Draught \\
& high & & & \\
\hline
\end{tabular}

In addition to questions about thermal comfort, the questionnaire also asked users perceptions of Gallery 1.

- What would you like to do here?

- What makes this place special?

The questionnaire held on August 26, 2019 at 1113.00 in sunny weather condition. All the respondents have to fill all the question as shown on figure

\section{Results and Discussions}

\subsection{Classification of Data}

The stages of analysis for this research object are as follows:

Classification of temperature data and indoor $\mathrm{RH}$ during the day and night, so that the following data were obtained: The average temperature is higher in the daytime at $28,78^{\circ} \mathrm{C}$, the slight difference at night is $287^{\circ} \mathrm{C}$. The highest daytime temperature in May is $29,52^{\circ} \mathrm{C}$, and at night $29,46^{\circ} \mathrm{C}$. The temperature at the lowest daytime in July is $27,91^{\circ} \mathrm{C}$ and at night $27,77^{\circ} \mathrm{C}$. This is evident from chart 1 . Relative humidity is higher at night with an average of $66,55 \%$, while during the day an average of $28,7 \%$. The highest $\mathrm{RH}$ was found in January during the day which is $70,85 \%$, and at night $71,82 \%$. The lowest $\mathrm{RH}$ is in July during the daytime which is $60,11 \%$ and the lowest at night is $60,17 \%$. This can be seen more clearly in Figure 11 and 12 .

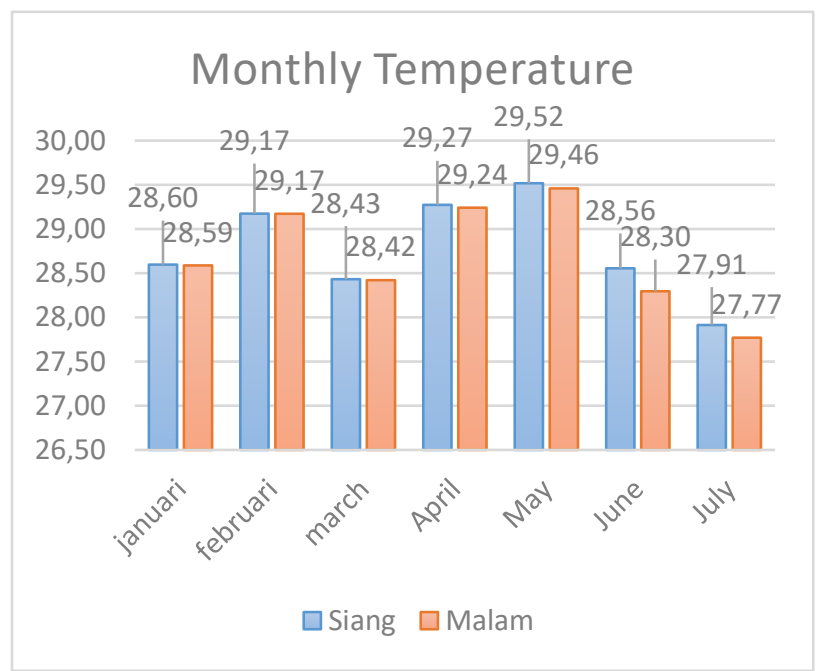

Figure 11. Monthly Indoor Temperature (Celsius) Source: Field Measurement (2019) 


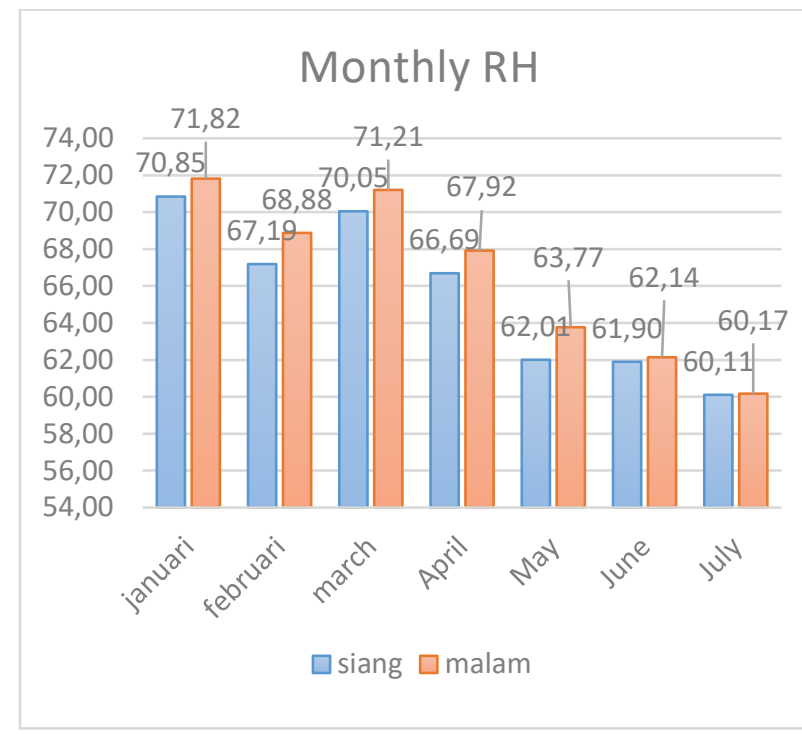

Figure 12. Monthly Indoor RH (\%)

Source: Field Measurement (2019)

TEMPERATURE AND RH AT GALLERY 1

- Temperature (C)

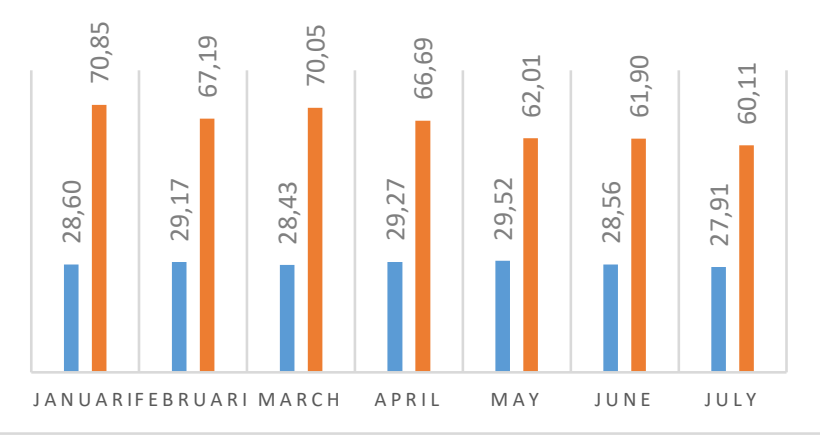

Figure 13. Average Monthly Indoor Temperature ( ${ }^{\circ} \mathrm{C}$ ) and $\mathrm{RH}$ (\%) Source: Field Measurement (2019)

Classification of temperature data and indoor relative humidity $(\mathrm{RH})$ during the day, so the following data were obtained: The average temperature in the daytime was $28,78^{\circ} \mathrm{C}$. The highest daytime temperature in May was $29,52^{\circ} \mathrm{C}$ and the lowest daytime in July was $27,91^{\circ} \mathrm{C}$. Relative Humidity during the day average of $65,54 \%$. The highest RH was found in January at $70,85 \%$, and the lowest $\mathrm{RH}$ was in July at $60,11 \%$. This can be seen more obvious in Figure 13.

\section{Analysis based on the 2010 ASHRAE standard}

The measurement data above is the basic data to be input into the ASHRAE CBE calculator that has been developed by Berkeley. The result of this calculator is a psychometric chat. The psychometric chart is a graphical display of air thermodynamic properties including temperature, humidity, enthalpy, moisture content, and specific volume. In this chart, it can be seen directly the relationship between various air parameters quickly and precisely, both related to the physical properties of the air and its thermal properties.

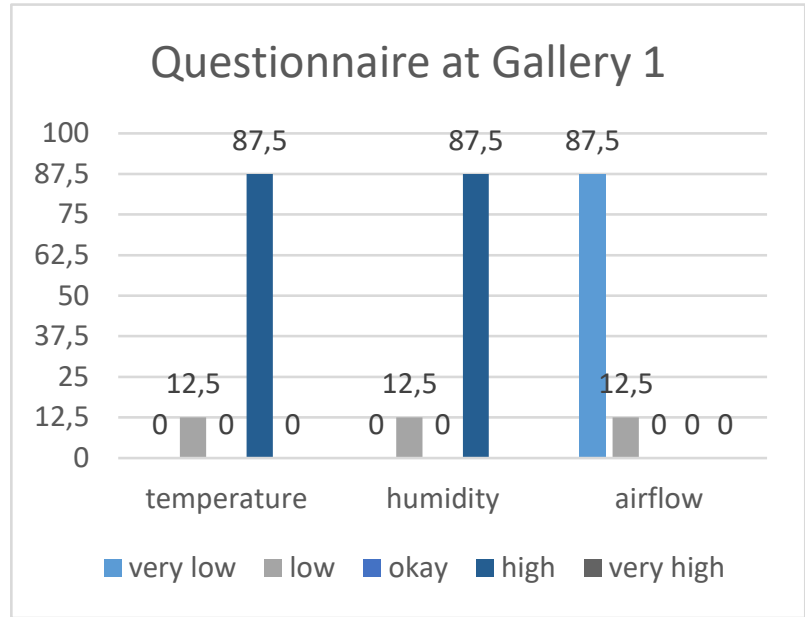

Figure 14. Questionnaire Result

Source: Author (2019)

The data was input monthly to see the level of convenience distribution per month. From the results of calculations according to the ASHRAE standard in the daytime condition in gallery 1 of the Affandi Museum turned out to be uncomfortable. This can be seen more clearly in Figure 13.

The thermal comfort position on the psychometric chart in Figure 14 can be seen in the blue area. While the thermal comfort distribution points of the building can be seen at monthly colorful points. The position of the monthly dots is completely outside the blue area, indicating the thermal comfort conditions are not achieved.

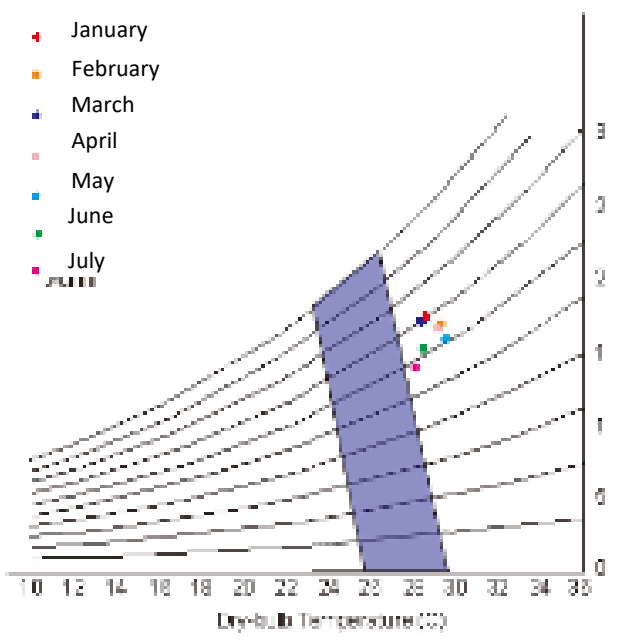

Figure 15. ASHRAE calculation- Monthly Average Source: http://comfort.cbe.berkeley.edu

Table 4. Measurement Input When Questionnaire Held on August 26, 2019

\begin{tabular}{lll}
\hline Temperature & 29,55 & $\mathrm{C}$ \\
\hline $\mathrm{RH}$ & 67,1 & $\%$ \\
\hline Wind Speed & 0,03 & $\mathrm{~m} / \mathrm{s}$ \\
\hline
\end{tabular}




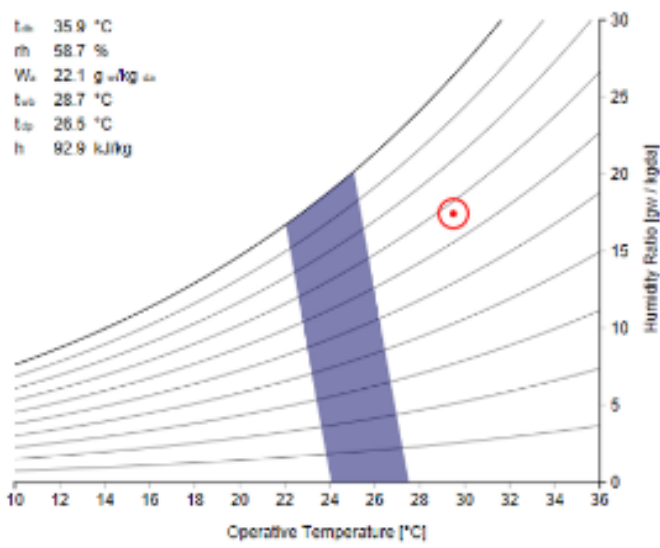

Figure 16. ASHRAE calculation in August 26, 2019 Source: http://comfort.cbe.berkeley.edu

\section{Questionnaire Result}

Questionnaire results at gallery 1 were $12,5 \%$ of the respondent felt low temperatures, $87,5 \%$ felt high temperatures, $12,5 \%$ respondent felt low $\mathrm{RH}$ and $87,5 \%$ felt high $\mathrm{RH}$. Meanwhile, $87,5 \%$ of the respondents felt low airflow and $12,5 \%$ felt fine. All respondents wore the same type of dress and did the same activities, stand, relaxed and enjoyed the artwork. The actual measurement at the gallery 1 was $29,55^{\circ} \mathrm{C}, 67,1 \% \mathrm{RH}$ and $0,03 \mathrm{~m} / \mathrm{s}$.

Based on ASHRAE standard high RH \& temperature while low airflow means the situation is not comfortable. The measurement result at the point of the questionnaire takes place. Based on ASHRAE psychometric chart the thermal comfort can be seen as Figure 15.

The thermal comfort position on the psychometric chart in Figure 15 can be seen in the blue area and the position of the dot is outside the blue area, indicating the thermal comfort conditions are not achieved in gallery 1 .

Table 5. Physical Setting on Gallery 1

\begin{tabular}{ll}
\hline Physical setting & Gallery 1 \\
\hline Ceiling & $\begin{array}{l}+7-8-\text {-meter, special structure, } \\
\text { special fabric and skylight }\end{array}$ \\
\hline Opening/ Natural ventilation & No \\
\hline River position & Bit Far \\
\hline Number of floors & 1 and mezzanine \\
\hline Void & yes \\
\hline Collection & $\begin{array}{l}\text { Affandi's personal car, the } \\
\text { award from government, } \\
\text { sculpture and oil painting }\end{array}$ \\
\hline
\end{tabular}

Although thermal comfort was not achieved in gallery 1 , the respondents voted $60 \%$ enjoyed the situation, $30 \%$ talked and $10 \%$ drank at gallery 1 . Most of the visitors at gallery 1 thought about the stage/mezzanine, the use of fabric in the skylight, arrangement or room layout, roof structure, light condition for art and the atmosphere makes the gallery 1 special. Many visitors wanted to improve the thermal conditions because gallery 1 feels too hot, low airflow and very humid. Some of the visitors also thought about lighting, space and wall paint.

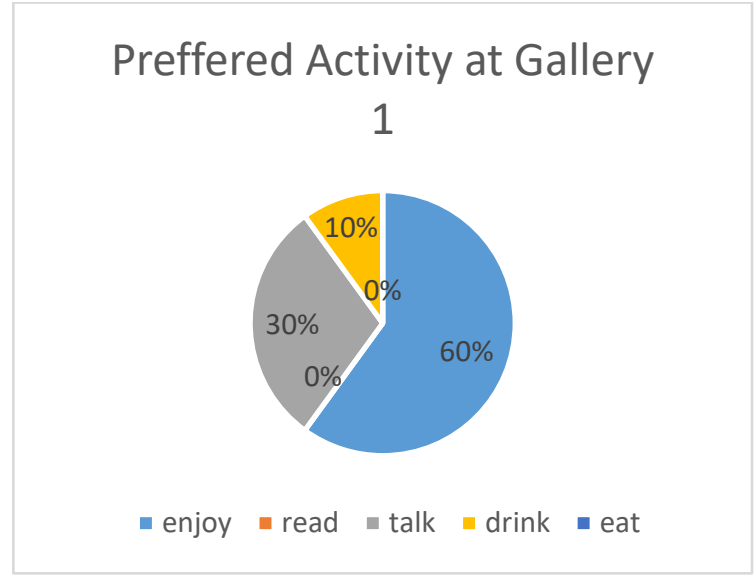

Figure 17. Preffered Activity at Gallery 1 Source: Author (2019)

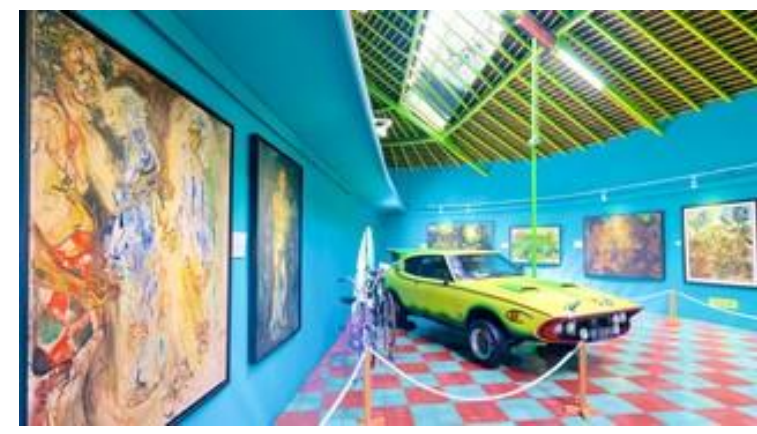

Figure 18. Gallery 1 Special Collection Source: Author (2019)

\section{Conclusion}

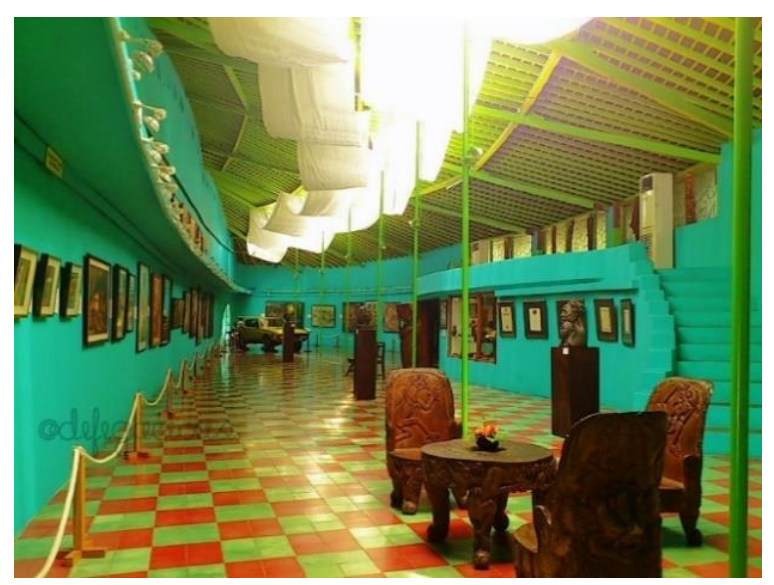

Figure 19. Gallery 1 Special Collection

Source: Author (2019)

Research conducted using the ASHRAE standard with physical and non-physical variables revealed that the thermal comfort in the Affandi museum was incompatible with the standards in the tropics. Physical variables in ASHRAE include temperature, $\mathrm{RH}$ and wind flow. While non-physical in the form of metabolism/activity and clothing/clo. Based on the measurement and questionnaire method, Gallery 1 with $87,5 \%$ respondents voted not comfortable. Although they voted for not comfort, they could enjoy gallery 1 . Like the main gallery, Gallery 1 has many special collections such as Affandi's personal car, 
some sculptures, Affandi's awards, and oil painting. In addition, gallery 1 has a special roof structure that resembles a banana leaf, a skylight, and fabric on it. Many visitors also wanted to improve gallery 1 thermal condition because gallery 1 feels too hot with low airflow and very humid.

\section{References}

Debiasse, K. (2010). An Analysis of the Influences of Human Thermal Comfort on the Attendance of Indoor Versus Outdoor Shopping Malls as a Result of Afternoon and Evening Meteorological Conditions. Journal of the Arizona- Nevada Academy of Science, 42(1), 15-25. DOI: 10.2181/036.042.0104

Handoko. (1994). Klimatologi Dasar (2nd ed). Bogor: Fakultas Matematika dan Ilmu Pengetahuan Alam Institut Pertanian Bogor

Kamus Besar Bahasa Indonesia. (2018, October 6). Nyaman. Retrieved from https://kbbi.web.id/nyaman

Lechner, N. (2000). Heating, Cooling, Lighting (2nd ed). Jakarta, Indonesia: PT. Rajagrafindo Persada

Maulidi, C. (2017). Pengaruh Tipologi Jalan Terhadap Kenyamanan Termal Pada Penghijauan Kampung Kota. Planning for Urban Regional and Environment, 6(1)

Mishra, A.K. and Ramgopal, M. (2013). Field Studies on Human Thermal Comfort - An overview. Building and Environment, 64, 94-106. DOI: 10.1016/j.buildenv.2013.02.015

Sangkertadi, S. and Syafriny, R. (2016). Pair Influence of Wind Speed and Mean Radiant Temperature on Outdoor Thermal Comfort of Humid Tropical Environment. Journal of Urban and Environmental Engineering, 10(2), 177-185. DOI: 10.4090/juee.2016.v10n2.177185

Satwiko, P. (2009). Fisika Bangunan. Yogyakarta: Andi.

Wikipedia. (2018, December 8). Iklim Mikro. Retrieved from https://id.wikipedia.org/wiki/Iklim_mikro 